\title{
A Comparison of the Processing Characteristics of Three Tanier Cultivars ${ }^{1}$
}

\author{
F. Sánchez Nieva ${ }^{2}$
}

\begin{abstract}
The processing characteristics of three tanier cultivars grown commercially in Puerto Rico (Blanca del Pais - white flesh; Rascana-cream-colored flesh; and Vinola - pink (flesh) were compared. When lye peeled in $15 \%$ lye, heated to 200 and $210^{\circ} \mathrm{F}\left(93,99^{\circ} \mathrm{C}\right)$ at the time of immersion, corresponding to the highest peeling efficiency, the Blanca cultivar suffered the highest loss in weight, followed in descending order by the Rascana and Vinola. The Blanca and Rascana cultivars were difficult to trim while the Vinola, because of its softer texture, could be trimmed without difficulty. The three cultivars when lye peeled suffered browning on exposure to air. The rate of the browning reaction in the Rascana cultivar was much less than in the other two. Besides browning, on exposure to air the Vinola suffered changes in the pink pigment of the flesh, with the result that a strong brownish red pigment developed around the stem end and at the point of emergence of the lateral roots. In the three cultivars, the browning reaction could be effectively controlled by a combination of a 2 -min dip in $1 \%$ citric acid solution followed by sulfitation to levels of $200 \mathrm{p} / \mathrm{m}$. The Blanca cultivar was found superior to the other two when cooked fresh or frozen. Processing, including the control of the browning reaction, made possible the preparation of frozen products of acceptable quality from the three cultivars.
\end{abstract}

\section{INTRODUCTION}

Small farmers in Puerto Rico produce taniers mainly for local consumption as fresh produce. Four types of cultivars are grown which differ among themselves in the size and shape of the tubers and the color of the flesh. According to the color of the flesh, these cultivars are classified as follows: white-Blanca del País and Viequera; creamRascana; yellow - Kelly; pink - Vinola, known also as Morada (1, 2, 3).

No information is available on the processing characteristics of any of these cultivars. This study was conducted to determine the effect of varietal characteristic on yield, behavior during processing, and quality of the frozen tubers. The study was limited to a comparison of the Blanca del País, Rascana, and Vinola cultivars. Cultivar Kelly was not available at the time.

\section{MATERIALS AND METHODS}

The three cultivars were purchased directly from farmers or from distribution centers operated by the Commonwealth Department of

Manuscript submitted to Editorial Board December 23, 1976.

${ }^{2}$ Chemical Engineer, Food Technology Laboratory, Agricultural Experiment Station, University of Puerto Rico, Río Piedras. Mr. I. Hernández, former Assistant Chemical Engineer, assisted in the processing tests, and Mrs. I. B. Caloni, Assistant Food Technologist, Food Technology Laboratory, conducted the organoleptic tests. 
Agriculture. The tubers were graded for size and only those ranging in diameter from $11 / 2-2$ inches $(3.7-5.0 \mathrm{~cm}$ ) were processed.

The tubers were soaked in water at room temperature for $10 \mathrm{~min}$ and then washed in a rod-reel washer with water sprays. The washed roots were peeled with $15 \%$ lye at $200^{\circ} \mathrm{F}\left(93^{\circ} \mathrm{C}\right)$ and at $210^{\circ} \mathrm{F}\left(99^{\circ} \mathrm{C}\right)$ as described by Sánchez Nieva et al. (6). Time of immersion in the lye bath varied from 4.5 to $9.5 \mathrm{~min}$. The lye-treated tubers were washed in a rotary-brush washer (Magnuwasher, Model F). ${ }^{3}$

To control browning, an acid dip and sulfitation were used (7). The tubers were dropped directly from the washer into a tank containing a $1 \%$ citric acid solution. After a 2-min dip in the acid solution, the tubers were sulfited by dipping for $5 \mathrm{~min}$ in a $0.5 \%$ by weight $\mathrm{K}_{2} \mathrm{~S}_{2} \mathrm{O}_{5}$ solution. Trimming was done as required to remove suberized tissue and other defects.

The tubers were packed in waxed cardboard containers which were overwrapped with vapor moistureproof wrapping paper. The product was frozen at $-40^{\circ} \mathrm{F}\left(-40^{\circ} \mathrm{C}\right)$ and stored at $-10^{\circ} \mathrm{F}\left(-23.3^{\circ} \mathrm{C}\right)$ until used.

For organoleptic tests the contents of one box (12 oz approx. $-320 \mathrm{~g}$ ) without thawing were cooked until tender in 2 cups $(.5 \mathrm{l})$ boiling water to which one teaspoon of salt was added.

Two methods of organoleptic evaluation were used: Rating for quality attributes, such as flavor, appearance, texture, intensity of off-flavor, and overall sample quality, using a 6-point hedonic scale; and ranking to compare the cultivars among themselves for flavor and appearance. When the rating method was used, single samples were presented to tasters under daylight. When the ranking method was used, the three cultivars were compared simultaneously under red light for flavor, and under daylight for appearance, each factor being judged independently. The results of the ranking tests were statistically analyzed by the ranksum method described by Kramer (4).

\section{RESULTS AND DISCUSSION}

\section{BEHAVIOR DURING LYE PEELING AND TRIMMING}

Table 1 gives the results obtained when peeling tubers of the Blanca, Rascana, and Vinola cultivars in $15 \%$ lye at $200^{\circ} \mathrm{F}\left(93^{\circ} \mathrm{C}\right)$ and at $210^{\circ} \mathrm{F}\left(99^{\circ} \mathrm{C}\right)$ varying the retention time in the lye bath from 4.5 to 9.5 $\min$.

When peeled at $200^{\circ} \mathrm{F}\left(93^{\circ} \mathrm{C}\right)$ the Blanca cultivar could be peeled with $100 \%$ efficency at an immersion time of $6.5 \mathrm{~min}$. Increasing the length of

3 Trade names are used in this publication solely for the purpose of providing specific information. Mention of a trade name does not constitute a guarantee or warranty of equipment or materials by the Agricultural Experiment Station of the University of Puerto Rico or an endorsement over other equipment or materials not mentioned. 
the lye treatment to $8 \mathrm{~min}$ increased peeling losses by about $3 \%$ with a slight decrease in peeling efficiency.

With the Rascana cultivar, the highest peeling efficiency obtained was $80 \%$ at a dipping time in the lye bath of $8 \mathrm{~min}$. Increasing the length of the lye treatment to $9.5 \mathrm{~min}$ increased peeling losses by about $12 \%$.

In the Vinola cultivar, the highest peeling efficiency obtained was $85 \%$. Increasing the length of the lye treatment $3 \mathrm{~min}$ had only a relatively small effect on peeling efficiency.

During the lye peeling at the time of immersion corresponding to highest peeling efficiency, the Blanca cultivar suffered the highest loss in weight followed in descending order by the Vinola and the Rascana.

TABLE 1. - Loss in weight of tubers and peeling efficiency obtained when lye-peeling taniers of the Blanca, Rascana, and Vinola varieties in $15 \%$ lye at $200^{\circ}$ and $210^{\circ} \mathrm{F}$

\begin{tabular}{cccc}
\hline Variety & Immersion time & Loss in weight of lye-peeled tubers & $\begin{array}{c}\text { Peeling effi- } \\
\text { ciency }\end{array}$ \\
\hline \multirow{4}{*}{ Blanca } & Min & $\%$ & $\%$ \\
Rascana & & Lye temperature $200^{\circ} \mathrm{F}\left(93^{\circ} \mathrm{C}\right)$ & \\
& 6.5 & 34.6 & 100.0 \\
& 8.0 & 37.1 & 95.0 \\
Vinola & 6.5 & 25.0 & 75.0 \\
& 8.0 & 27.3 & 80.0 \\
& 9.5 & 37.5 & 55.0 \\
& 4.5 & 29.2 & 27.8 \\
& 6.5 & 30.7 & 85.0 \\
Blanca & 8.0 & 34.6 & 80.0 \\
& 9.5 & 30.7 & 85.0 \\
Rascana & & Lye temperature $210^{\circ}$ & \\
& 6.5 & 35.5 & $\left.89^{\circ} \mathrm{C}\right)$ \\
& 7.5 & 37.7 & 100.0 \\
Vinola & 9.3 & 41.1 & 70.0 \\
& 4.5 & 25.0 & 75.0 \\
& 6.5 & 30.4 & 80.0 \\
& 8.0 & 33.3 & 55.0 \\
& 4.5 & 25.0 & 75.0 \\
& 6.5 & 30.7 & 85.0 \\
& 8.0 & 30.7 & 75.0 \\
& 9.5 & 39.2 & 85.0 \\
\hline
\end{tabular}

The peel was completely removed in all three cultivars at the dipping time corresponding to the highest peeling efficiency. The lower peeling efficiency obtained with the Rascana and Vinola cultivars was attributed to a higher incidence of wounds and suberized tissue in the samples processed.

Similar results were obtained when peeling the three cultivars with lye at $210^{\circ} \mathrm{F}\left(99^{\circ} \mathrm{C}\right)$.

Table 2 gives the results obtained when processing representative lots of the three cultivars under the same processing conditions. During lye 
peeling the Blanca cultivar suffered the highest loss in weight and the Rascana the smallest, confirming the results obtained from the previous experiment (table 1).

The loss in weight due to trimmings to remove suberized tissue and blemished areas was higher in the Vinola cultivar, followed in descending order by the Rascana and the Blanca. The higher trimming losses resulting when processing the Rascana and Vinola cultivars was due to a high incidence of suberized tissue and blemished areas in the sample processed. This was probably due to the fact that the Vinola and Rascana cultivars were purchased from a distribution center and were perhaps kept longer in storage than the samples of the Blanca cultivar which were purchased directly from a farmer.

The three varieties exhibited different characteristics during trimming. The Blanca cultivar was found to be very slippery, which made trimming difficult. The Rascana cultivar was less slippery than the Blanca but was found to be somewhat hard, also making trimming difficult. The Vinola variety was less slippery and softer than the other two, which facilitated the trimming operation. Irizarry et al. (3) in a study of the effect of time of planting and age at harvest on the

TABle 2. - Peeling and trimming losses resulting when lye-peeling the Blanca, Rascana, and Vinola varieties in $15 \%$ lye at $200^{\circ} \mathrm{F}\left(93^{\circ} \mathrm{C}\right)$ for 6.5 minutes

\begin{tabular}{lccc}
\hline \multicolumn{1}{c}{ Variety } & Blanca & \multicolumn{1}{c}{ Rascana } & Vinola \\
\hline $\begin{array}{l}\text { Average weight of tubers - lbs; (g) } \\
\text { Weight loss of tubers during lye- }\end{array}$ & $0.19(87.0)$ & $0.26(118.0)$ & $0.21(96.0)$ \\
$\begin{array}{l}\text { peeling - \% } \\
\text { Weight loss from trimmings - \% }\end{array}$ & 2.01 & 31.00 & 26.50 \\
\hline
\end{tabular}

marketable yield and quality of four tanier cultivars reported that a 2mo delay in harvest softened the texture of the cultivars Blanca del País, Rascana, Kelly, and Morada. Based on shear-press measurements these authors concluded that the Blanca del País and Morada cultivars had a softer texture than the Kelly and Rascana. The behavior during a trimming of the three varieties studied confirm these results.

\section{BROWNING OF THE LYE-PEELED TUBERS}

When lye-peeled tubers of the Blanca cultivar are exposed to the air, rapid browning takes place in the area around the stem end and at the point of emergence of the lateral roots as well as in any bruised exposed surface (7).

The Rascana and the Vinola cultivars exhibited a somewhat different behavior on exposure to air after lye peeling. In the Rascana cultivar the browning reaction takes place at a much slower rate than in the Blanca. Brown discoloration appears slowly on exposure to air and is generally 
localized around the stem end and at the point of emergence of the lateral roots. On trimming, the cut surface developed browning at a very slow rate.

The Vinola lye-peeled tubers suffered a very strong browning reaction at a rate as fast or faster than that observed in the lye-peeled tubers of the Blanca cultivar. In this cultivar, two distinct types of discoloration were observed: The development of the typical dark pigment characteristic of enzymatic browning; and the intensification of the reddish color of the pigment present, which is characteristic of the cultivar. On exposure to air the combined effect of both types of discoloration resulted in the development of an intense brownish-red color at the stem end and lateral root tips which, on further exposure to air, turned darker. The exposed surface of the tubers developed a pinkish-violet color, looking mottled. These changes in color greatly detracted from the appearance of the tubers.

In potatoes, the rate of browning varies with variety, site of growth, and seasonal changes in climate $(5,8)$. Observations made by the author suggest that in taniers the rate of browning varies not only with varietal characteristics but seems to be affected also by ecological factors. It has been repeatedly observed that tubers of the Blanca cultivar harvested from different zones of Puerto Rico differed in the rate of browning. Tubers grown in the Yabucoa area were found to exhibit a very fast and strong browning reaction after lye peeling.

\section{CONTROL OF THE BROWNING REACTION}

Sánchez Nieva et al. (7) showed that the enzymatic browning of the lye-peeled tubers of the Blanca cultivar could be effectively controlled by dipping the tubers in $1 \%$ citric acid solution immediately after peeling and before trimming followed by sulfitation to a level of $200 \mathrm{p} / \mathrm{m}$.

The Rascana variety, which has a light-cream flesh, behaved similarly to the Blanca cultivar with acid treatment and sulfitation. The acid dip controlled browning during trimming, and sulfitation to levels of $200 \mathrm{p} / \mathrm{m}$ was enough to control browning during freezing and storage. The combined acid and sulfitation treatments were found to have no adverse effect on flavor.

Table 3 shows the effect of two acid treatments on the organoleptic properties of lye-peeled tubers of the Vinola cultivar. Dipping the tubers for $2 \mathrm{~min}$ in $1 \%$ and $3 \%$ citric acid solution had no effect on flavor when the acid-treated samples were ranked together with lye-peeled tubers without further treatment and with hand-peeled tubers. Dipping in 1\% citric acid improved the appearance of the lye-peeled tubers. The handpeeled tubers were rejected for inferior appearance, not only in comparison with the acid-treated sample but also with the lye-peeled samples. 
The fact that the lye-peeled tubers were found superior in appearance to those hand peeled suggested that heating had some effect on the discoloration of the tubers due to the combined effect of browning and changes in the pink pigment of the flesh. However, when lye-peeled tubers were blanched in water for $5 \mathrm{~min}$ at $175^{\circ} \mathrm{F}\left(79.5^{\circ} \mathrm{C}\right)$ and for 3 and $5 \mathrm{~min}$, respectively at $195^{\circ} \mathrm{F}\left(90.5^{\circ} \mathrm{C}\right)$, no further improvement in appearance was observed.

Sulfitation was found to improve the appearance of the Vinola tubers without adversely affecting the flavor. It was observed that sulfitation by dipping for 5 min in $1 \%$ by weight $\mathrm{K}_{2} \mathrm{~S}_{2} \mathrm{O}_{5}$ solution, besides controlling the browning reaction, bleached the pink pigment of the flesh. The sulfited tubers looked whiter after the sulfiting treatment, which greatly improved their appearance.

\section{ORGANOLEPTIC PROPERTIES OF FRESH AND PROCESSED TUBERS}

The results of ranking tests in which hand-peeled tubers of the three cultivars cooked without any further treatment were compared for flavor and appearance show that tasters found all three cultivars similar in flavor but selected the Blanca cultivar as superior in appearance.

TABLE 3.-Effect of acid treatments on the organoleptic properties of lye-peeled tubers of the Vinola cultivar

\begin{tabular}{lcc}
\hline \multicolumn{1}{c}{ Treatments tested } & \multicolumn{2}{c}{ Rank sums $^{1}$} \\
\cline { 2 - 3 } & Flavor & Appearance \\
\hline Lye-peeled, washed with water & 37 & 34 \\
Lye-peeled plus 2-min dip in 1\% citric acid solution & 28 & $20^{*}$ \\
Lye-peeled plus 2-min dip in 3\% citric acid solution & 28 & 29 \\
Hand-peeled with no further treatment & 37 & $47^{* *}$ \\
\hline
\end{tabular}

${ }^{1}$ Rank sums for significant difference among samples for 13 tasters, 4 samples: at $5 \%$ P: $23-42$; at $1 \%$ P: $21-44$.

The results of similar ranking tests in which lye-peeled, acid-treated, trimmed, and sulfited frozen samples were compared for flavor and appearance showed no significant difference among the cultivars in flavor, but again the Blanca cultivar was selected as the best from the standpoint of appearance.

In ranking, the three cultivars were compared among themselves only for flavor and appearance. To determine the quality of the frozen products prepared from each, they were submitted separately to sensory evaluation using a 6-point hedonic scale to rate the different quality attributes. The results of these tests are given in table 4 .

The Blanca cultivar was scored higher for appearance, flavor, and overall sample quality than the Rascana and the Vinola. The Vinola was scored lowest in all quality attributes measured. 
The Blanca cultivar was found softer than desirable, while the texture of the Vinola and Rascana was found typical of a boiled tanier. This suggests that the Blanca cultivar requires less cooking after freezing than the other two.

According to table 4 frozen products of acceptable quality could be prepared from the three cultivars.

The results of this study show that the three tanier cultivars, Blanca del País, Rascana, and Vinola are similar in flavor, differing mainly in appearance when cooked either fresh or processed. Processing, including lye-peeling, acid dip, and sulfitation, does not affect the flavor but greatly improves the appearance by controlling the browning reaction in all three cultivars and by bleaching the pink color of the Vinola. Although the Blanca cultivar is definitely superior to the other two cultivars, both raw and processed, processing and freezing make possible the preparation of products of acceptable quality from all three cultivars.

TABLE 4.-Results of sensory evaluation of the frozen taniers using hedonic scales to measure overall quality, appearance, flavor, texture, and the presence of off-flavors

\begin{tabular}{|c|c|c|c|c|c|}
\hline Variety & Appearance & Flavor & $\begin{array}{c}\text { Off-fla- } \\
\text { vors }\end{array}$ & Texture. & $\begin{array}{l}\text { Overall } \\
\text { quality }\end{array}$ \\
\hline Blanca & $\begin{array}{l}\text { Moderately attractive } \\
(4.9)\end{array}$ & $\begin{array}{l}\text { Good } \\
(4.8)\end{array}$ & $\begin{array}{l}\text { None } \\
(5.7)\end{array}$ & $\begin{array}{l}\text { Soft } \\
(2.3)\end{array}$ & $\begin{array}{l}\text { Good } \\
(4.4)\end{array}$ \\
\hline Vinola & $\begin{array}{l}\text { Acceptable, slightly } \\
\text { attractive } \\
(3.5)\end{array}$ & $\begin{array}{l}\text { Good } \\
(4.1)\end{array}$ & $\begin{array}{l}\text { None } \\
(5.5)\end{array}$ & $\begin{array}{l}\text { Typical of boiled } \\
\text { taniers } \\
(3.1)\end{array}$ & $\begin{array}{l}\text { Fair } \\
(3.9)\end{array}$ \\
\hline Rascana & $\begin{array}{l}\text { Slightly attractive } \\
(4.4)\end{array}$ & $\begin{array}{l}\text { Good } \\
(4.2)\end{array}$ & $\begin{array}{l}\text { None } \\
(5.8)\end{array}$ & $\begin{array}{l}\text { Typical of boiled } \\
\text { taniers } \\
(3.2)\end{array}$ & $\begin{array}{l}\text { Fair } \\
(4.2)\end{array}$ \\
\hline
\end{tabular}

\section{RESUMEN}

Se comparó el comportamiento durante la elaboración para congelar la calidad del producto congelado de tres variedades comerciales de yautía producidas en Puerto Rico. Las variedades fueron: la Blanca del País, de pulpa blanca; la Rascana, de pulpa crema; y la Vinola, de pulpa color de rosa pálido.

Cuando las tres variedades se pelaron con lejía al $15 \%$ por peso a $200^{\circ} \mathrm{F}$. $\left(93^{\circ} \mathrm{C}\right.$.) y a $210^{\circ} \mathrm{F}$. $\left(99^{\circ} \mathrm{C}\right.$.) se observó que la variedad Blanca sufrió la mayor pérdida de peso, siguiéndole en orden descendente la Rascana y la Vinola. De las tres variedades, la Blanca pudo pelarse con mayor eficiencia que las otras dos.

Cada variedad se commportó distinto al recortarla después de peleada. A la Blanca, por ser resbalosa, y a la Rascana, por ser algo dura, fue difícil recortarles las áreas dañadas. Pero la Vinola, por su textura blanda, fue fácil recortarla.

Al quedar expuestas al aire después del tratamiento con soda, las tres variedades sufrieron un pardeamiento enzimático que dio lugar al desarrollo de manchas obscuras en los extremos y alrededor del punto de salida de las raicillas laterales. El obscurecimiento en la Rascana procedió en forma más lenta que en la Blanca. En la Vinola el color rosado de la pulpa se obscureció también al quedar expuesta al aire afectándose adversamente la apariencia.

El pardeamiento pudo controlarse eficazmente en las tres variedades tratando las yautías, ya peladas, con una solución de ácido cítrico al $2 \%$ seguido de una sulfitación hasta un nivel de $\mathrm{SO}_{2}$ de alrededor de 200 p.p.m. 
La variedad Blanca probó ser superior a las otras dos cuando se cocinó fresca así como congelada. No obstante, por medio de técnicas de elaboración apropiadas que incluyen la remoción de la cáscara con soda caústica y los tratamientos de ácido y sulfitación para controlar el pardeamiento también se pudo preparar tubérculos congelados de calidad aceptable de las otras dos variedades.

\section{LITERATURE CITED}

1. Estación Experimental Agrícola, Colegio de Ciencias Agrícolas Recinto de Mayagüez, Universidad de Puerto Rico, Conjunto Tecnológico para la Producción de Cosechas Farinaceas, Est. Exp. Agric. Univ. P. R., Publicación 101: 20, 1976.

2. Irizarry, H., and Acosta-Matienzo, A., Effect of plant density on marketable yield, tuber number and mean weight of three tanier cultivars, J. Agric. Univ. P.R. 58(1): 37-43, 1974.

3. — - Badillo, J., and Rivera, J. B., Effect of time of planting and age at harvest on marketable yield and quality of four tanier cultivars, J. Agric. Univ. P.R. 60(3): 253-61, 1976.

4. Kramer, A., A rapid method for determining the significance of differences from rank sums, Food Technol. 14(11): 576-81, 1960.

5. Mapson, L. W., Swain, T., and Tomalin, A. W., Influence of variety, cultural conditions and temperature of storage on the enzymatic browning of potato tubers, J. Sci. Food Agric. 14: 673-84, 1963.

6. Sánchez Nieva, F., and Hernández, I., Lye peeling of taniers, J. Agric. Univ. P.R. 61(3): 345-53, 1977.

7. - Control of browning in lye peeled taniers, J. Agric. Univ. P.R. (in press).

8. Talburt, W. F., and Smith, O., Potato Processing, The Avi Publishing Co., Westport Conn.: 88-90, 1967. 